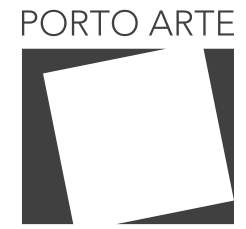

Revista de Artes Visuais

V.25 n. 43

Jan/jun 2020

e-ISSN: 2179-8001

\title{
Germinares $^{1}$
}

Germination $^{2}$

\section{Catiuscia Dotto}

ORCID: https://orcid.org/0000-0002-5691-7024

Instituição: doutoranda PPGAV UFRGS / Professora EBTT IFSUL Campus Camaquã

\section{Resumo}

A série de esculturas Germinares surge no contexto da pandemia do Corona Vírus que determinou a situação de isolamento social. Toda minha investigação escultórica evoca o feminino em sua simbiose com a natureza, traduzido em formas orgânicas, em elementos de volume e vazio, em equilíbrios e desequilíbrios. Aqui, o retorno à origem... A forma, que antes se expandia no espaço, timidamente, e com requinte, apenas ousa germinar, ou quem sabe, retorna para seu interior mais íntimo.

Palavras chave

Arte Contemporânea. Artes Visuais. Escultura.

\section{Abstract}

The Germination sculpture series appears in the context of the Corona Virus Virus pandemic that determined the situation of social isolation. All my sculptural research evokes the feminine in its symbiosis with nature, translated into organic forms, into elements of volume and emptiness, into balances and imbalances. Here, the return to the origin ... The form, which previously expanded in space, timidly, and with refinement, only dares to germinate, or who knows, returns to its most intimate interior.

Keywords:

Contemporary Art. Visual arts. Sculpture. 


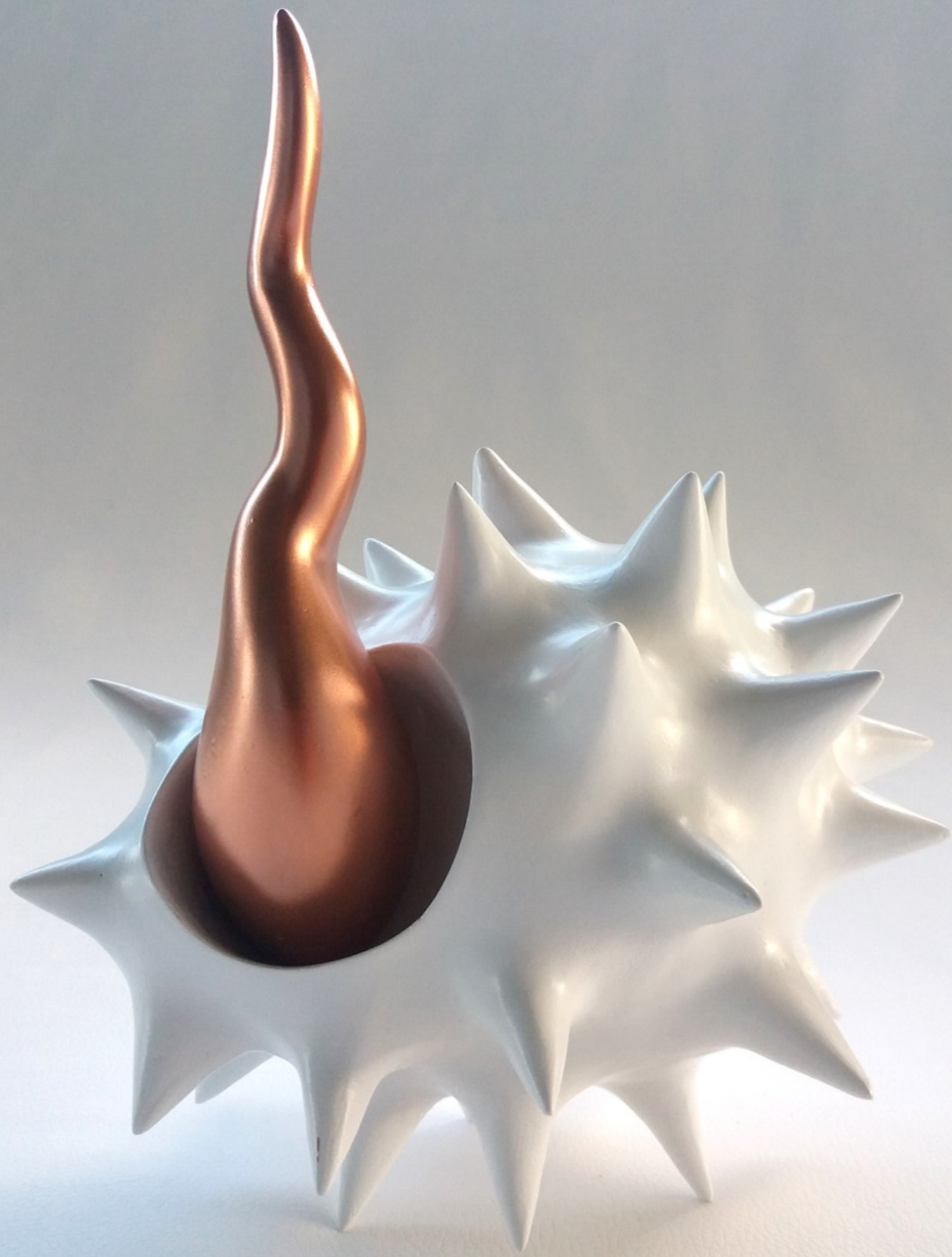




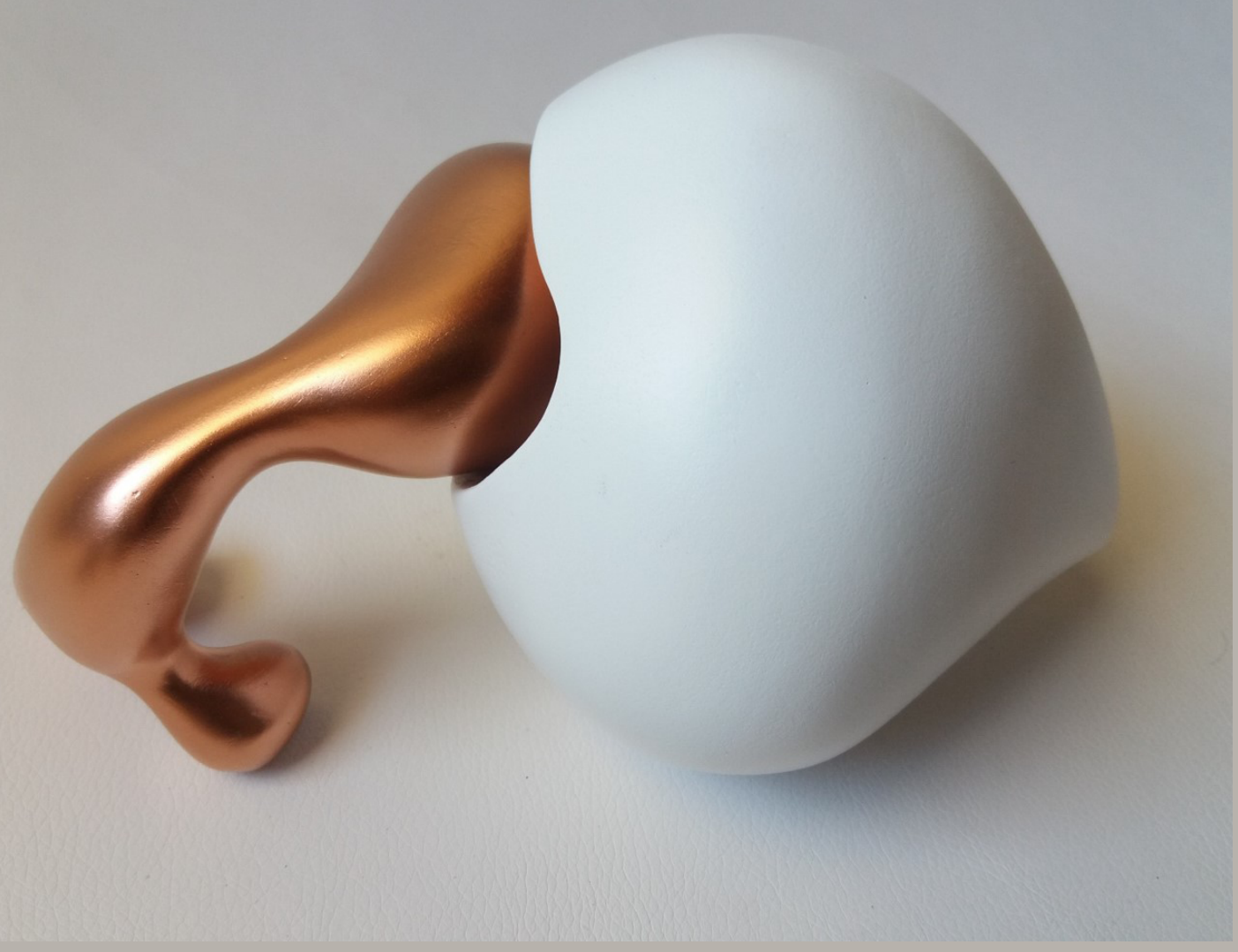




$$
4
$$




$$
\frac{2}{2}
$$






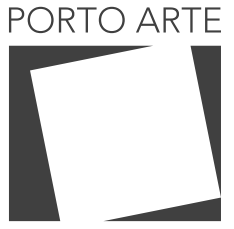

Revista de Artes Visuais

v. 25 ก. 43

\section{Catiuscia Dotto}

Catiuscia Dotto é Escultora e Arte/Educadora. Mestre em Artes Visuais pela UFSM e doutoranda em Poéticas Visuais no PPGAV da UFRGS, permeia entre a prática artística e a docência. Transcorre uma investigação escultórica que constrói a partir do feminino buscando simbioses que transitam pelo imaginário e pelas vivências. É professora do Instituto Federal Sul-rio-grandense - Câmpus Camaquã 